Tyas Nyonita Punjungsari, Agung Setya Wibowo, Intan Fuji Arriani \& Palupi Puspitorini 2019. Eksplorasi Konsorsium PBRM (Plant Beneficial Rhizospheric Microorganism) Dalam NUE (Nutrient Use Efficiency) pada Pertumbuhan Jagung (Zea mays L) Journal Viabel Pertanian. (2019), 13(2)11-15

\title{
EKSPLORASI KONSORSIUM PBRM (PLANT BENEFICIAL RHIZOSPHERIC MICROORGANISM) DALAM NUE (NUTRIENT USE EFFICIENCY) PADA PERTUMBUHAN JAGUNG (Zea mays L)
}

\author{
${ }^{1)}$ Tyas Nyonita Punjungsari ${ }^{2)}$ Agung Setya Wibowo ${ }^{3)}$ Intan Fuji Arriani \\ ${ }^{4)}$ Palupi Puspitorini \\ Fakultas Pertanian Universitas Islam Balitar \\ Email : ${ }^{1)}$ tyasnyonita@gmail.com, ${ }^{2}$ agungsetyawibowo1@gmail.com, \\ ${ }^{3)}$ Intanfuji485@gmail.com, ${ }^{4)}$ puspitorini.palupi@gmail.com
}

\begin{abstract}
PBRM (Plant Beneficial Rhizospheric Microorganism) is a microbe that is able to form colonies in plant roots (rhizosphere) that have the ability to fix nitrogen $(\mathrm{N})$, and dissolve potassium $(\mathrm{K})$, phosphorus $(\mathrm{P})$, and zinc $(\mathrm{Zn})$.

Increasing NUE can increase plant growth through various mechanisms. Population and dynamics of rhizosphere microorganisms are different from other soil microorganisms, this is caused by an increase. The purpose of this study was to determine the type of rhizosphere bacteria that can be as PBRM. The method used The research was conducted at the Microbiology Laboratory of the Faculty of Agriculture, Brawijaya University, Malang. The characterization process was carried out in UB's microbiology laboratory. 50 grams of soil for planting corn were put into an erlenmeyer containing 500 $\mathrm{ml} \mathrm{NB}$ (for bacteria) and $500 \mathrm{ml}$ liquid PDA (for mold) and then incubated with the secretary for about 24 hours and then diluted in series to a dilution rate of 10-3,10-4,10 5. Then from the dilution factor of 10-3,10-4,10-5 $0.1 \mathrm{ml}$ is taken and inoculated in solid media by the pour plate method. The results showed that the antagonistic rhizosphere bacteria were $P$. fluorescens, B. subtillis, and Rhizobium sp.
\end{abstract}

Kata Kunci : PBRM, NUE, Corn

\section{PENDAHULUAN}

PBRM (Plant Beneficial rhizospheric microorganism) adalah mikrobia yang mampu membentuk koloni didaerah perakaran tanaman (rhizosphere) yang memiliki kemampuan dalam memfiksasi nitrogen $(\mathrm{N})$, dan melarutkan kalium $(\mathrm{K})$, phosphor $(\mathrm{P})$, dan zinc (Zn).

Peningkatan NUE dapat meningkatkan pertumbuhan tanaman memalui berbagai mekanisme (Meena et al, 2017). Populasi dan dinamika mikroorganisme rhizosphere berbeda dengan mikroorganisme tanah lainnya, hal ini disebabkan oleh peningkatan. Kelompok mikroorganisme PBRM yang berperan bagi pertumbuhan tanaman dan penyerapan makro serta mikromineral yang dibutuhkan tanaman adalah bakteri Acinetobacter, Alcaligenes, Arthrobacter, Azobacter, Azosprillum, Bacillus, Beijerinckia, Burkholderia, Burkholderia, Klebsiella, Mycobacterium, Paenibacillus, Phyllobacterium, Pseudomonas, Rhizobia, Rhizobium, Serratia, Sinorhizobium, Sphingomonas, Streptomyces, dan Variovorax. Selain berperan dalam penyerapan nutrisi tanaman, penggunaan PBRM juga ramah lingkungan. Mikroorganisme PBRM juga berperan penting dalam degradasi nutrient yang terakumulasi ditanah untuk mengurangi toksisitasnya terhadap ekosistem.

Penggunaan satu spesies atau genus mikrloorganisme sebagai agen biologis PBRM memiliki nilai ekonomis yang tinggi selain itu proses isolasi yang diperlukan untuk 
Tyas Nyonita Punjungsari, Agung Setya Wibowo, Intan Fuji Arriani \& Palupi Puspitorini 2019. Eksplorasi Konsorsium PBRM (Plant Beneficial Rhizospheric Microorganism) Dalam NUE (Nutrient Use Efficiency) pada Pertumbuhan Jagung (Zea mays L) Journal Viabel Pertanian. (2019), 13(2)11-15

menyiapkan agen biologis akan membutuhkan waktu yang lama. Oleh karena itu sebaiknya agen biologis yang digunakan adalah konsorsium PBRM. Ada banyak bukti bahwa PBRM disekitar rhizosfer mampu meningkatkan ketersediaan nutrisi untuk tanaman. Metode yang dilakukan PBRM adalah dengan meningkatkan fiksasi Nitrogen, pelarutan nutrient, memproduksi siderophore, dan produksi ammonia. Selain itu dengan adanya mikroorganisme rizhosper dapat membantu degradasi logam dalam tanah dan dapat membantu pengikatan unsur kalium yang dapat dimanfaatkan oleh tanaman. Kandungan metal yang banyak dalam tanah akan menyebabkan akumulasi logam yang berlebihan. Keadaan ini dapat menyebabkan terganggunya proses pertumbuhan tanaman, dan juga pengambilan ion Fe. Sidherophore yang dihasilkan oleh bakteri rhizosphere akan membantu dalam penyerapan Fe oleh akar tanaman. Phospor. Sehingga ekplorasi mikroorganisme PBRM pada tanah bekas kacang tanah diharapkan akan diperoleh mikroorganisme yang mampu meningkatkan NUE (Nutrient Use Efficiency) pada tanaman jagung.

\section{METODE PENELITIAN}

Penelitian dilakukan di Laboratorium Mikrobiologi Fakultas Pertanian, Universitas Brawijaya, Malang.

Proses karakterisasi dilakukan di laboratorium mikrobiologi UB. 50 gram tanah untuk menanam jagung dimasukkan dalam erlenmeyer berisi $500 \mathrm{ml} \mathrm{NB}$ (unuk bakteri) dan 500 ml PDA cair (untuk kapang) kemudian diinkubasi dengan sekker sekitar 24 jam kemudian dilakukan pengenceran secara seri sampai tingkat pengenceran 10-3,10-4,10-5. Kemudian dari faktor pengenceran 10-3,10-4,10-5 diambil 0,1ml dan diinokulasi pada media padat dengan metode pour plate. Kultur yang tumbuh akanmembentuk koloni pada sub surface media ataupun pada permukaan media. Setelah dilakukan pour plate dilakukan inokulasi dengan metode streak dan dikarakterisasi.

HASIL DAN PEMBAHASAN

Tabel 1. Hasil Uji Indentifikasi Baktri 3 Dominan Sebelum Tanam

\begin{tabular}{|c|l|c|c|}
\hline $\begin{array}{c}\text { Kode } \\
\text { Sampel }\end{array}$ & \multicolumn{1}{|c|}{ Hasil Identifikasi } & $\begin{array}{c}\text { Populasi } \\
\text { (CFU/g) }\end{array}$ & \multicolumn{1}{|c|}{ Metode Pengujian } \\
\hline \multirow{3}{*}{$\cdot$} & Bacillus subtilis & $5,3 \times 10^{7}$ & Total Plate Count, Selective medium \\
\cline { 2 - 4 } & Pseudomonas fluorecens & $4,9 \times 10^{7}$ & Total Plate Count, Selective medium \\
\cline { 2 - 5 } & Rhizobium Sp. & $8,1 \times 10^{6}$ & Total Plate Count, Selective medium \\
\hline
\end{tabular}


Tyas Nyonita Punjungsari, Agung Setya Wibowo, Intan Fuji Arriani \& Palupi Puspitorini 2019. Eksplorasi Konsorsium PBRM (Plant Beneficial Rhizospheric Microorganism) Dalam NUE (Nutrient Use Efficiency) pada Pertumbuhan Jagung (Zea mays L) Journal Viabel Pertanian. (2019), 13(2)11-15

Tabel 2. Hasil Analisis Uji Identifikasi Bakteri 3 Dominan Setelah Tanam

\begin{tabular}{|c|l|c|c|}
\hline $\begin{array}{c}\text { Kode } \\
\text { Sampel }\end{array}$ & \multicolumn{1}{|c|}{ Hasil Identifikasi } & \multicolumn{1}{|c|}{$\begin{array}{c}\text { Populasi } \\
\text { (CFU/g) }\end{array}$} & \multicolumn{1}{|c|}{ Metode Pengujian } \\
\hline \multirow{3}{*}{$\cdot$} & Bacillus subtilis & $9,4 \times 10^{8}$ & Total Plate Count, Selective medium \\
\cline { 2 - 5 } & Pseudomonas fluorecens & $4,5 \times 10^{8}$ & Total Plate Count, Selective medium \\
\cline { 2 - 5 } & Rhizobium Sp. & $7,1 \times 10^{7}$ & Total Plate Count, Selective medium \\
\hline
\end{tabular}

Berdasarkan hasil ekplorasi dan isolasi didapatkan atau diperoleh beberapa spesies bakteri antagonis yang berguna dalam meningkatkan pertumbuhan tanaman yaitu bakteri Pseudomonas fluorecens, Bacillus subtillis dan Rhizobium sp. Bakteri P. fluorescens adalah jenis mikroorganisme yang hidup di daerah perakaran tanaman yang secara intensif berinteraksi berinteraksi dengan perakaran tanaman maupun tanah, selain itu, bakteri $P$. fluorescens dapat mengendalikan beberapa jenis penyakit (Khaeruni et al. 2014). Bakteri $P$. fluorescens dapat berkolonisasi dengan daerah perakaran tanaman untuk menginduksi tanaman dengan memproduksi fitolakesin dan asam salisilat yang mempunyai peranan untuk meningkatkan ketahanan tanaman (Soesanto et al. 2014). Selain itu, bakteri $P$. fluorescens mampu menghasilkan zat pengatur tumbuh, seperti hormon sitokinin, auksin, giberelin dan senyawa IAA di dalam tanaman (Soesanto et al. 2011; Rahni 2012).

Dalam upaya meningkatkan produktivitas tanaman jagung yaitu dengan berbagai cara salah satunya dengan pemberian hormon pemacu pertumbuhan tanaman atau yang disebut dengan PBRM (Plant Beneficial Rhizospheric Microorganism) yang dihasilkan oleh mikroorganisme yang hidup didaerah perakaran tanaman atau rhizosfer khususnya perakaran tanaman jagung, yang diduga terdapat mikrorogasme Rhizobium yang berkoloni dengan bintil akar tanaman. PBRM (Plant Beneficial Rhizospheric Microorganism) dewasa ini sudah banyak dilaporkan berbagai manfaat dalam meningkatkan pertumbuhan tanaman dan kesuburan lahan tanam yaitu dengan kemampuannya dalam melakukan kolonisasi perakaran tanaman (Raka et al., 2012).

Dalam pemberian PBRM (Plant Beneficial Rhizospheric Microorganism) terdapat prinsip yang dapat dilakukan yaitu memperbanyak dan meningkatkan populasi mikrooeganisme aktif yang terdapat didaerah sekitar perakaran tanaman yang dapat meningkatkan pertumbuhan dari tanaman yang sedang dibudidayakan. Beberapa manfaat yang terdapat dalam PBRM (Plant Beneficial Rhizospheric Microorganism) sendiri yaitu mampu mingkatkan kadar mineral tanah dan fiksasi nitrogen yang sangat dibutuhkan dalam meningkatkan pertumbuhan dari tanaman. Selain itu, manfaat dari pemberian PBRM (Plant Beneficial Rhizospheric Microorganism) yaitu sebagai agen biokontrol dalam mengendalikan berbagai macam serangan OPT, memberikan tolerasi tanaman terhadap cekaman, bermanfaat sebagai biofertilizer, mensekresi enzim khususnya enzim litic, mampu meningkatkan IAA atau indol-3-aceticdan mampu menginduksi ISR (Kumar et al., 2011). Menurut Zhao et al., 2015 mikrooeganisme yang berpotensi sebagai PBRM yaitu $B$. subtilis. Berdasarkan hasil penelitian yang telah dilakukan menunjukkan bahwa bakteri B. subtillis memiliki kemampuan dalam menginduksi tanaman (Dewi et al., 2015). Berberapa penelitian menyatakan bahwa isolat bakteri B. subtillis mempunyai kemampuan dalam menghasilkan enzim protease, senyawa IAA. Senyawa IAA adalah hasil senyawa metabolit sekunder yang dihasilkan oleh agens hayati atau mikrooeganisme yang mempunyai peranan dalam meningkatkan perkembangan sel dan memcau pertumbuhan, merangsang pembentukan akar baru. Menurut Wong. (2005) terdapat 
Tyas Nyonita Punjungsari, Agung Setya Wibowo, Intan Fuji Arriani \& Palupi Puspitorini 2019. Eksplorasi Konsorsium PBRM (Plant Beneficial Rhizospheric Microorganism) Dalam NUE (Nutrient Use Efficiency) pada Pertumbuhan Jagung (Zea mays L) Journal Viabel Pertanian. (2019), 13(2)11-15

inokulum spesies bakteri yaitu Bacillus megaterium dan Bacillus mucilaginous yang dapat meningkatkan pertumbuhan dan produksi tanaman jagung dan dilaporkan dapat meningkatkan asimilasi unsur hara tanaman seperti (N, P dan K).

Beberapa jenis spesies bakteri salah satunya isolat Bacillus mempunyai beberapa mekanisme PBRM dalam meningkatkan produksi tanaman salah satunya sebagai biofertillizer yang mempunyai peranan yaitu fiksasi N2, dapat memproduksi siderofor dan pelarut fosfat (Kumar et al., 2011). Senyawa siderofor mempunyai beberapa peran yaitu mampu meningkatkan ketahanan tanaman terhadap serangan OPT dan induksi resistensi. Menurut Masnilah et al., 2006 tanaman yang diberikan perlakuan bakteri yang termasuk kedalam PBRM mampu meningkatkan pertumbuhan akar tanaman. Tanaman yang terdapat mikroorganisme Bacillus mampu melarutkan fosfat hingga 2-3 kali lebih banyak (Vessey, 2003).

Pemberian PBRM bekas tanaman kacang tanah diharapkan akan terdapat mikrooeganisme yang mampu berkolonisasi dengan nodul perakaran tanaman salah satunya yaitu bakteri Rhizobium. Bakteri Rhizobium adalah mikroorganisme yang mempunyai kemampuan untuk menyediakan unsur hara tanaman. Kelompok bakteri ini bersimbiosis dengan tanaman legum dan selanjutnya menginfeksi akar tanaman sehingga membentuk bintil akar. Bakteri Rhizobium melakukan fiksasi nitrogen atmosfer apabila berada di dalam bintil akar dari tanaman legumnya. Rhizobium mempunyai peranan dalam meningkatkan pertumbuhan tanaman dengan cara menyediakan ketersediaan nitrogen bagi tanaman. Didalam bintil akar akan dijumpai atau terdapat pigmen merah yang biasa disebut dengan leghemoglobin yang terdapat dalam bakteriod dan selubung membran yang mengelilinginya. Jumlah leghemeglobin yang terdapat di bintil akar mempunyai keterkaitan langsung terhadap jumlah nitrogen yang difiksasi (Rao, 1994 dalam Rahmawati, 2005). Bakteri Rhizobium pada umumnya efektif dengan hanya satu spesies tanaman legum ataupun dalam setiap kultivar kacangkacangan. Menurut Suryantini (1994) dalam Nasikah (2007) beberapa spesies Rhizobium yaitu Bradyrhizobium spp. bersimbiosis dengan kacang tanah sedangkan Rhizobium phaseoli bersimbiosis dengan kacang hijau.

\section{KESIMPULAN}

Berdasarkan hasil ekplorasi didapatkan beberapa spesies bakteri rhizosfer yang bersifat antagonis yaitu P. fluorecens, B. subtillis dan Rhizobium sp. Dari hasil isolasi sebelum tanaman dengan sesudah tanam menunjukkan peningkatan jumlah koloni.

\section{UCAPAN TERIMAKASIH}

Penulis menyampaikan ucapan terima kasih yang sebesar-besarnya Kepada :

1. Rektor Universitas Islam Balitar Blitar

2. Kemenristekdikti yang telah mendanai Penelitian dengan Dana Riset dan Pengabdian Masyarakat (DRPM) melalui Skema Penelitian Dosen Pemula

3. Semua pihak yang telah mendukung terlaksananya penelitian ini. 
Tyas Nyonita Punjungsari, Agung Setya Wibowo, Intan Fuji Arriani \& Palupi Puspitorini 2019. Eksplorasi Konsorsium PBRM (Plant Beneficial Rhizospheric Microorganism) Dalam NUE (Nutrient Use Efficiency) pada Pertumbuhan Jagung (Zea mays L) Journal Viabel Pertanian. (2019), 13(2)11-15

\section{DAFTAR PUSTAKA}

Khaeruni A, Wahab A, Taufik M, Sutariati GAK. 2013. Keefektifan waktu aplikasi formulasi rizobakteri indigenus untuk mengendalikan layu Fusarium dan meningkatkan hasil tanaman tomat di tanah ultisol. J Hort. 23(4):365-371.

Soesanto L, Mugiastuti E, Rahyuniati RF. 2011. Biochemical characteristic of Pseudomonas fluorescens P60. J Biotech Biodiver. 2:19-26.

Soesanto L, Mugiastuti E, Rahayuniati RF. 2014. Aplikasi formula cair Pseudomonas fluorescens P60 untuk menekan penyakit virus cabai merah. J Fitopatol Indones. 9(6): 179-185. DOI: http://dx.doi. org/10.14692/jfi.9.6.179.

Yan Z, Reddy MS, Ryu CM, Melnroy JA, Wilson M, Kloepper JW. 2002. Induced systemic protection against tomato late blight elicited by plant growth promoting rhizobacteria. J Phytopathol. 92:1329- 1333. DOI: http://dx.doi.org/10.1094/ PHYTO.2002.92.12.1329.

Dewi, T. K., E. S. Arum, Imamuddin dan S. Antonius. 2015. Karakterisasi Mikrobia Perakaran (PGPR) Agen Penting Pendukung Pupuk Organik Hayati. Prosiding Seminar Nasional Masyarakat Biodivercity Indonesia. 1(2): 289-295.

Kumar, A., A. Prakash., and B.N. Johri. 2011. Bacillus as PGPR in Crop Ecosystem. Bacteria in Agrobiology; Crop Ecosystem. In: D. K. Maheshwari (eds).Bacteria in Agrobiology: Crop Ecosystems.pp 37-59.

Wu, S. C and M. H. Wong. 2005. Effect of Biofertilizer Containing N-fixer, P and K Solubilizers and AM Fungi on Maize Growth; a Greenhouse Trial. Geoderma. 125: $1-2$.

Surtiningsih, T., Farida, dan T. Nurhariyati. 2009. Biofertilisasi Bakteri Rhizobium pada Tanaman Kedelai (Glycine max(L) Merr.). Berk. Penel. Hayati, 15 : 31-35 